\title{
Maternal protein depletion and small-for-gestational-age babies
}

\author{
HARRY STEIN \\ From the Department of Paediatrics, Baragwanath Hospital and University of the Witwatersrand, \\ Johannesburg, South Africa
}

\begin{abstract}
Stein, H. (1975). Archives of Disease in Childhood, 50, 146. Maternal protein depletion and small-for-gestational-age babies. It has been established that there is a high incidence of small-for-gestational-age babies among underprivileged urban Africans. This community suffers from endemic malnutrition. Serum albumin studies on mothers of low birthweight babies showed a direct correlation with size of babies for gestational age.

Thus maternal protein depletion, and probably therefore malnutrition, was associated with the high incidence of small-for-age-gestational babies.
\end{abstract}

It has recently been established that an exceptionally high incidence of small-for-gestational-age babies exists among underprivileged urban Africans (Stein and Ellis, 1974), the reasons for which are uncertain. Apart from multiple pregnancy, other known aetiological factors of small-for-gestationalage babies, such as toxaemia of pregnancy and intrauterine infection, play little or no part.

Because of the endemic malnutrition in this population it seemed likely that this would be of significance. There was, however, little overt clinical malnutrition among the mothers in this study. Nevertheless, biochemical evidence of maternal protein depletion as reflected by low serum albumin levels may be a more sensitive index of malnutrition than the clinical presentation. This study assesses such biochemical features in the mothers of small-for-gestational-age babies, and correlates this with fetal growth.

\section{Investigation}

One hundred and three mothers of single low birthweight babies admitted consecutively to our nursery were examined and serum albumin levels were estimated by the electrophoretic method (Smith, 1960). Midmorning, nonfasting venous blood samples were taken between the second and fourth days postnatally. Mothers of twins were excluded as these had previously been shown to contribute to the high incidence of small-for-gestational-age babies seen (Stein and Ellis, 1974). The babies of these mothers were weighed, examined, and gestational age estimated by the method

Received 10 July 1974. of Dubowitz, Dubowitz, and Goldberg (1970). This method has been shown to be reliable in similar population groups (Brueton, Palit, and Prosser, 1973; Singer, Blake, and Wolfsdorf, 1973; Jaroszewicz and Boyd, 1973). The weight and gestational age of the babies were correlated using the chart of Battaglia and Lubchenco (1967). The association between centiles of birthweight related to gestational age of the babies and serum albumin levels of the mothers was investigated. Maternal serum albumin levels below $30 \mathrm{~g} / 1$ were accepted as evidence of protein depletion and babies below the 10th centile of birthweight for gestational age were regarded as being small for gestational age.

Statistical evaluation was carried out on standard principles (Bradford Hill, 1971).

\section{Results}

Of the 103 mothers, 54 had serum albumin levels of $30 \mathrm{~g} / 1$ or above and 49 had levels below $30 \mathrm{~g} / 1$. Of the 103 babies born to these mothers 42 were on or above the 10th centile of weight for gestational age (appropriate for gestational age) and 61 were below the 10th centile of weight for gestational age (small for gestational age).

Of the 54 mothers whose serum albumin levels were $30 \mathrm{~g} / \mathrm{l}$ or above, $30(56 \%)$ had babies who were appropriate for gestational age and $24(44 \%)$ had babies who were small for gestational age. Of the 49 mothers whose serum albumin levels were less than $30 \mathrm{~g} / 112(24 \%)$ had babies who were appropriate for gestational age and $37(76 \%)$ had babies who were small for gestational age (Fig.). Comparison of maternal serum albumin levels in the appropriate-for and small-for-gestational-age baby 


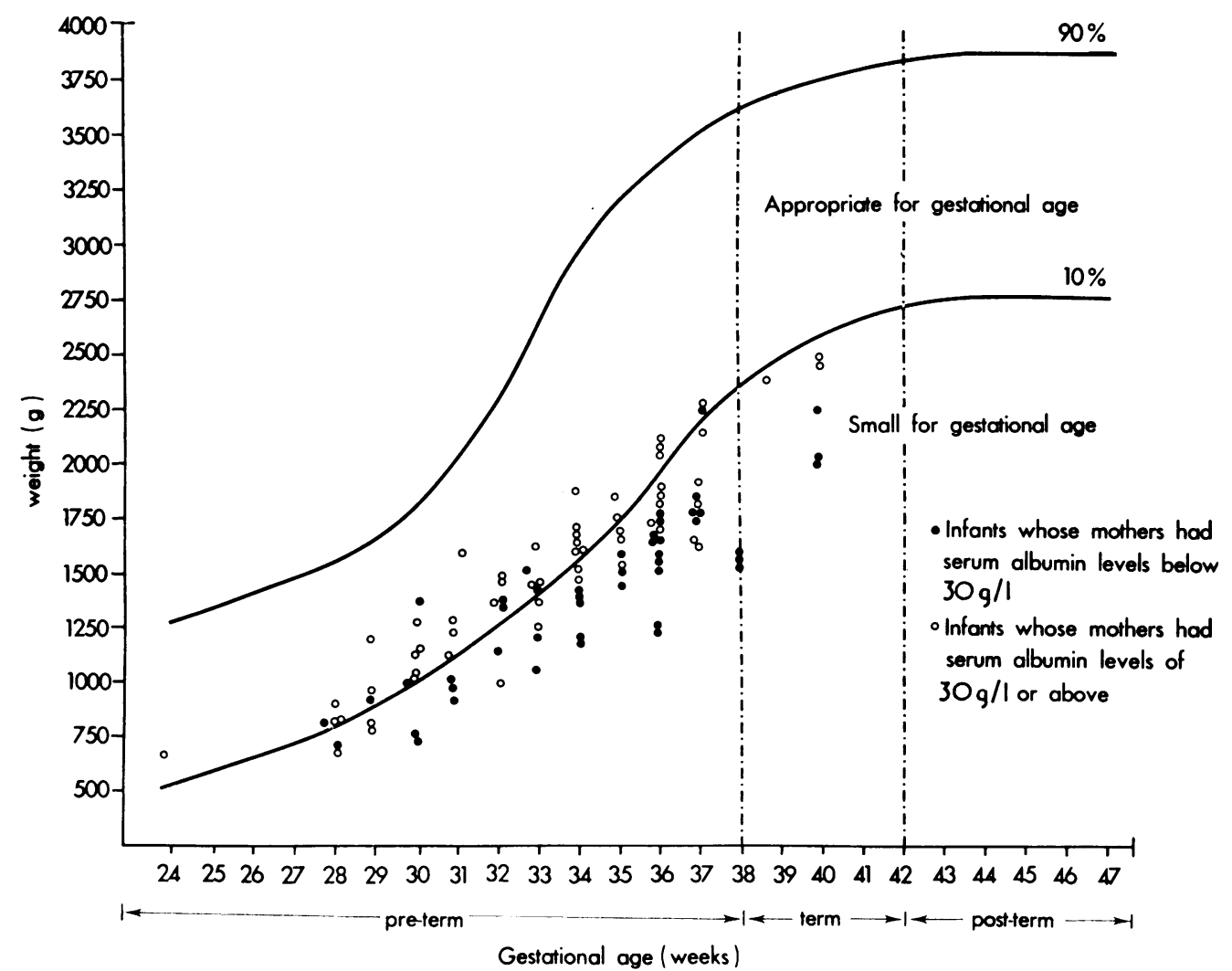

FIG. Cases plotted on chart relating birthweights and gestational age of infants to maternal serum albumin levels.

groups shows a statistically significant difference $(t=62$, no. $=101, P<0.0005)$.

On more detailed analysis a correlation exists between maternal serum albumin levels and the percentage of the 50th centile of the babies' weight for gestational age in the small-for-gestational-age group ( $r=0.47$ ) but this falls away in the appropriate-for-gestational-age group $(r=0.005)$ and the difference between these two is significant $(\mathbf{P}<0.01)$.

\section{Discussion}

The role of maternal malnutrition in the aetiology of small-for-gestational-age babies is unclear. Studies by Smith (1947) and Antonov (1947) during the war showed that acute starvation in mothers had relatively little effect on their babies' birthweights. Moreover, Ounsted (1971) and Drillien (1970) felt that the effect of maternal malnutrition on birthweight is slight.

There is nevertheless other evidence that the birthweight of children of underprivileged and undernourished mothers is below average (Moodie et al., 1970; Donelly et al., 1964; Naeye, 1972).

Our previous investigation (Stein and Ellis, 1974) showed a high incidence of small-for-gestational-age babies in an underprivileged population. It therefore remains to be established whether this was due to maternal malnutrition.

From this study it is apparent that there is indeed a correlation between low maternal serum albumin levels and the birth of small-for-gestational-age babies. This cannot be explained on the basis of the normal serum albumin variation during pregnancy. Though these levels fall during pregnancy there is a stabilization during the last trimester and in the early postnatal period (De Alvarez, Afonso, and Sherrard, 1961; MacDonald and Good, 1971).

Protein depletion is an index of malnutrition, and it is significant that malnutrition is endemic and chronic in the population under review. It therefore seems that whereas acute starvation has little effect on fetal growth, protein depletion, as 
part of the picture of chronic malnutrition, may indeed be significant in the aetiology of small-forgestational-age babies.

I wish to thank Professors J. D. L. Hansen and S. Wayburne, and Dr. Margaret Ounsted for help and encouragement with this investigation and Dr. U. Ellis for access to cases; Professor L. Schamroth for help with the manuscript, Dr. N. Buchanan for the statistics, the Photographic Unit of the Department of Medicine for the chart, and the Superintendent of Baragwanath Hospital for permission to publish this paper.

\section{REFERENCES}

Antonov, A. N. (1947). Children born during siege of Leningrad in 1942. Fournal of Pediatrics, 30, 250.

Battaglia. F. C., and Lubchenco, L. O. (1967). A practical classification of newborn infants by weight and gestational age. Four nal of Pediatrics, 71, 159.

Bradford Hill, A. (1971). Principles of Medical Statistics, 9th ed., The Lancet, London.

Brueton, M. J., Palit, A. and Prosser, R. (1973). Gestational age assessment in Nigerian newborn infants. Archives of Disease in Childhood, 48, 318.

De Alvarez, R. R., Afonso, J. F., and Sherrard, D. J. (1961). Serum protein fractionation in normal pregnancy. American fournal of Obstetrics and Gynecology, 82, 1096.

Donellv, J. F., Flowers, C. E., Creadick, R. N., Wells, H. B. Greenberg, B. G., and Surles, K. B. (1964). Maternal, fetal, and environmental factors in prematurity. American fournal of Obstetrics and Gynecology 88, 918.
Drillien, C. M. (1970). The small-for-date infant: etiology and prognosis. Pediatric Clinics of North America, 17, 9.

Dubowitz, L. M. S., Dubowitz, B., and Goldberg. C. (1970) Clinical assessment of gestational age in the newborn infant. Fournal of Pediatrics, 77, 1.

Jaroszewicz, A. M., and Boyd, I. H. (1973). Clinical assessment of gestational age in the newborn. South African Medical fournal, 47, 2123.

MacDonald, H. N., and Good, W. (1971). Changes in plasma total protein, albumin, urea and alpha-amino nitrogen concentrations in pregnancy and the puerperium. Fournal of Obstetrics and Gynaecology of the British Empire, 78, 912.

Moodie, A. D., Hansen, J. D. L., Jordaan, H. V. F., Malan, A. F., and Davey, D., (1970). Low-weight Cape Coloured mothers and their infants. South African Medical fournal, 44, 1400.

Naeye, R. L. (1972). The epidemiology of perinatal mortality. Pediatric Clinics of North America, 19, 295.

Ounsted, M. (1971). Fetal growth. In Recent Advances in Paediatrics, 4th ed., p. 34. Ed. by D. Gairdner and D. Hull, Churchill, London.

Singer, B., Blake, L., and Wolfsdorf, J. (1973). Estimation of gestational age of African newborn infants by a scoring system. South African Medical fournal, 47, 2074.

Smith, C. A. (1947). Effects of maternal undernutrition upon the newborn infant in Holland (1944 to 1945). Fournal of Pediatrics, 30, 229.

Smith, I. (1960). Chromatographic and Electronic Techniques, vol. 2, p. 18. Heinemann, London.

Stein, H. ,and Ellis, U. (1974). The low birthweight African baby. Archives of Disease in Childhood, 49, 156.

Correspondence to Dr. H. Stein, 18 Komatie Road, Emmerentia Extension, Johannesburg, South Africa.

The following articles will appear in future issues of this journal:

Leucocyte function in children with kwashiorkor. E. U. Rosen, J. Geefhuysen, R. Anderson, M. Joffe, and A. R. Rabson.

Agar in the management of hyperbilirubinaemia in the premature baby. C. Romagnoli, G. Polidori, M. Foschini, L. Cataldi, P. De Turris, G. Tortorolo, and R. Mastrangelo.

Selective impairment of growth hormone response to physiological stimuli. $P . H$. Wise, R. B. Burnet, T. D. Geary, and H. Berriman.

Insulin release in cystic fibrosis. N.I. M. Kjellman and Y. Larsson.

Calcium balance in children treated with diphosphonates. W. S. Uttley, N. R. Belton, J. Syme, and H. Sheppard.

Factors influencing breast feeding. K. Sloper, L. McKean, and J. D. Baum.

Bacteroides fragilis septicaemia and meningitis in early infancy. $R$. W. I. Cooke.

Bile acid excretion after pull-through operation for Hirschsprung's disease. H. Gaze, G. M. Murphy, R. Nelson, J. J. Corkery, C. M. Anderson.

Serum cortisol concentrations in children with chronic renal insufficiency. $P . R$. Betts, P. M. Howse, R. Morris, and P. H. W. Rayner. 